\title{
The Facies and Metamorphism Types Determination of Metamorphic Rock in The Part of Mekongga Complex
}

\author{
M. Musnajam ${ }^{1 *}$, Ahmad Tarmizi Abd Karim²,N. Nurfadillah ${ }^{3}$, Fahrudi Ahwan Ikhsan ${ }^{4}$, \\ Andri Estining Sejati ${ }^{5}$ \\ ${ }^{1}$ Mining Engineering Study Program, Universitas Sembilanbelas November Kolaka, \\ Jl. Pemuda 339, Kolaka, 93561, Indonesia \\ ${ }^{2}$ Faculty of Civil and Environmental Engineering, Universiti Tun Hussein Onn Malaysia, \\ Parit Raja, Batu Pahat Johor, 86400, Malaysia \\ ${ }^{3}$ Department of Geology Engineering, Universitas Halu Oleo, Kampus Hijau \\ Bumi Tridharma Anduonou, Kendari, 93132, Indonesia \\ ${ }^{4}$ Department of Geography Education, Universitas Jember, \\ J1. Kalimantan 37, Jember, 68121, Indonesia \\ ${ }^{5}$ Geography Education Study Program, Universitas Sembilanbelas November Kolaka, \\ Jl. Pemuda 339, Kolaka, 93561, Indonesia \\ *Corresponding Author : musnajam3@gmail.com
}

Received 5 April 2020/ Revised 15 July 2020 / Accepted 21 July 2020/ Available Online 28 July 2020

\begin{abstract}
Lambolemo Village is geomorphologically dominated by hilly slopes morphology. Lithology in the form of metamorphic rocks are mica schists and chlorite schists. The present research aimed to determine the facies and metamorphism types of metamorphic rocks in Lambolemo Village. The research methods engaged were field observation and laboratory observation utilizing petrographic analysis. Observations stage generated texture data and set of mineral both macroscopically and microscopically. The minerals were discovered within metamorphic rock of the research area, namely: muscovite, quartz, biotite, and chlorite. These findings then classified into two zones, there were chlorite zone and biotite zone. These zones were embodied into greenschist facies with chlorite mineral index. The greenschist facies was characterized with chlorite, albit, epidote, and actinolite minerals appearance. The metamorphic rock had a foliation structure. The structure was commonly generated by a regional metamorphic process, which was particularly a feature of the clear alignment, translucent minerals from flat minerals, such as : mica, chlorite and minerals that obtained fibers or scents.
\end{abstract}

Keywords: Determination; Facies; Metamorfism Type

\section{Introduction}

The rock cycle illustrates the process of rock formation, started from magma to magma. Rock that located in extreme deep point experiences changes from pressure and temperature. According to Ahmed et al. (2017) the process of rock forming until turns to 
magma is known as the rock cycle. According to (Kurnianto et al., 2018) Ijen Volcano existence is the example of volcanic rock deposits producing, which means rock is derived from magma.

The deep zone rock, once reaches a certain temperature, would melt into magma. Rock that have not reached the melting zone then changes into metamorphic rock. The process is known as the metamorphism process. According to Hasria et al. (2017) metamorphic rock development is a result of magma and pressure. According to (Ca et al., 2019) one of the basement rocks envolved is metamorphism.

The metamorphism process leads texture and mineral composition from previous rock changed. Both of these components could determine facies metamorphism that formed in a region zone. Metamorphic facies is metamorphic rock group with similar condition which is characterized by a group of permanent mineral. According to Geng et al. (2018) facies metamorphism in China is the outlined of the metamorphic rock map zone.

Lambolemo Village is an area located in Samaturu District, Kolaka Regency. This area is geomorphologically dominated with the sloping hills. Based on the pre-research stage, the lithology of this area was composed of metamorphic mica schist and chlorite schist. Then, the findings of mineral rock composition were optic mineral, facies, and metamorphism types.

Referring to the geological map of the Lasusua-Kendari sheet, this area is dominated by metamorphic rocks. The region is attached to the mekongga complex which is the oldest rock constituent formation in the Southeast Arm of Sulawesi. According to Hamimu et al. (2019) there are two metamorphic rock complexes in Southeast Sulawesi, namely pompangeo complex and mekongga complex.

Considering the results of early measurements of foliation upon research location, metamorphic rocks were generally dominated by the southeast-northwest direction. The southeast-northwest direction was the general direction of the strike slip fault on the southeastern arm of Sulawesi. Referring to Surono (2013) both Kolaka fault and the Konaweha fault are active and affecting the surrounding rock. Furthermore, according to (Maulana et al., 2018) the fault direction likely affect the development of metamorphic rock zone.

The research object was simulating, since it recorded complex geological information. Research regarding rock determinism which concerned facies and metamorphism types in the Mekongga complex has not been conducted. Geological maps were slightly limited to the general type of rocks. According to Tóth \& Schubert (2018) the formation of complex metamorphic rocks has become a distinctive study as in the Körös Complex in Hungary. 
The relevant research (Soesilo et al., 2015) identified the metamorphism type of metamorphic belt in the area between Java Sea and Mangkalihat Peninsula and also western part of Central Sulawesi. The research (Setiawan et al., 2015) revealed the metamorphic evolution through determining the facies and metamorphism type of meratus complex in South Kalimantan. The research (Chen et al., 2018) investigated the metamorphic rocks in Wuliangshan Mountains with the facies and metamorphism types.

Nugraha \& Hall (2018) focused in Wallace biodiversity area that determined the petrology and heavy mineral with depositional environments. The research (Moniruzzaman et $a l ., 2014)$ concerned in determining the mineral elements for human nutritions. The research (Kurnianto \& Nurdin, 2020) conducted observation of rock stratigraphy by investigating the patterns and types of rocks and also engaging Digital Elevation Model (DEM) and medium format photo.

There have been limited studies concerned on how to determine the other minerals (facies and metamorphism type such as depositional, nutrients, and DEM). Therefore, this research intended to collect detail findings relating metamorphic rocks that were not tagged neither in the geological map nor in other rock research within mekongga complex section. The objective of this research was to determine the facies and metamorphism types of metamorphic rock in part of mekongga complex in Lambolemo Village, Samaturu District, Kolaka Regency, Southeast Sulawesi, Indonesia.

\section{Methods}

The research types of this study were field research and laboratory research. Field research in the sense of lithological observation and measurement of foliation. While, laboratory research in the form of rock slice obsevaration sample used petrographic methods. This research was conducted in May, 2017 in Lambolemo Village, Samaturu District, Kolaka Regency, Southeast Sulawesi. According to (Anggara et al., 2018) the petrographic method is engaged in obtaining the microscopic data.

The research data consisted of primary and secondary data. Primary data was attained from direct observations in the field and laboratory analysis results of the texture and mineral type of metamorphic rocks. Field data in the form of lithology and foliation data, while the results of laboratory analysis in the form of texture and mineral type of metamorphic rocks. Secondary data was obtained from regional geological maps within research area. According to (Idrus et al., 2014) regional geological map performs as a complement in analyzing the metamorphic rock complex. According to (Amaluddin et al., 2019; Nursalam et al., 2019) 
geological and geography maps are functioning as additional and instant information for research. The research instruments is described in the table 1 below.

Table 1. The Research Instruments

\begin{tabular}{clc}
\hline No. & \multicolumn{1}{c}{ Instrument } & \multicolumn{1}{c}{ Functions } \\
\hline 1. & $\begin{array}{l}\text { Topography Map on scale } \\
1: 25.000\end{array}$ & $\begin{array}{c}\text { Based map for field orientation, plotingfield point } \\
\text { observation, and identified topography condition. }\end{array}$ \\
2. & GPS (Global Positioning Sistem) & \multicolumn{1}{c}{$\begin{array}{c}\text { Recorded the coordinate point } \\
\text { 3. }\end{array}$ Geology compass } \\
4. & Geology hammer & Collected sampling \\
5. & Loupe & Observed the rock constituent minerals in the field \\
6. & Field note & Media to record data observation \\
7. & Stationery & Recorded the results of field observations \\
8. & Meterrol & Measured outcrop dimensions \\
9. & Sample bag & A safety to put rock samples \\
10. & Camera & Captured images \\
11. & Microscope & Investigated rock samples microscopically \\
\hline
\end{tabular}

Research procedures followed 4 steps. First step was preparation. Preparation is all kinds of preparation activities regarding field equipment and literature study. Field equipment has been described in table 1 above. Literature study was objected to determine regional geological conditions, research methods and literature of metamorphic rocks. Second step was collecting both primary and secondary data.

Third step was data analysis. During this step, rock samples were selected for petrographic analysis. The rock samples being analyzed were sliced with a thickness of 0.03 $\mathrm{mm}$ and $0.05 \mathrm{~mm}$ to be observed under a polarization microscope. The tool used in analyzing metamorphic rocks was a Nikon UFX-DX series magnification of the 10X ocular lens and 10X, 20X and 40X magnification objective lenses. The meaning of microscopic,since it used the polarization microscope to determine the slice of minerals. The macroscopic means to analyze the mineral not guiding by microscope or determination by direct observation.

Fourth was formulating conclusion based on rock samples observation using petrographic method as the results of texture and metamorphic rock minerals similarities within the reseach area. According to this data, it could be used to determine the metamorphism facies formed in the reseach area and the metamorphism type of the research 
area by investigating the classification of metamorphism facies and the metamorphism type determination. The Figure 1 shows the research flow diagram.



Figure 1. Research flow diagram

\section{Results and Discussion}

The research area covered two types of rocks namely mica schist and chlorite schist. Macroscopic and microscopic description of mica schist macroscopically had a gray appearance in fresh condition and brown-colored in weathered condition. Rock texture was lepidoblastic, with foliation rock structure. The mineral composition were muscovite, quartz, and biotite. Figure 2 shows the rock figure of mica schist location.

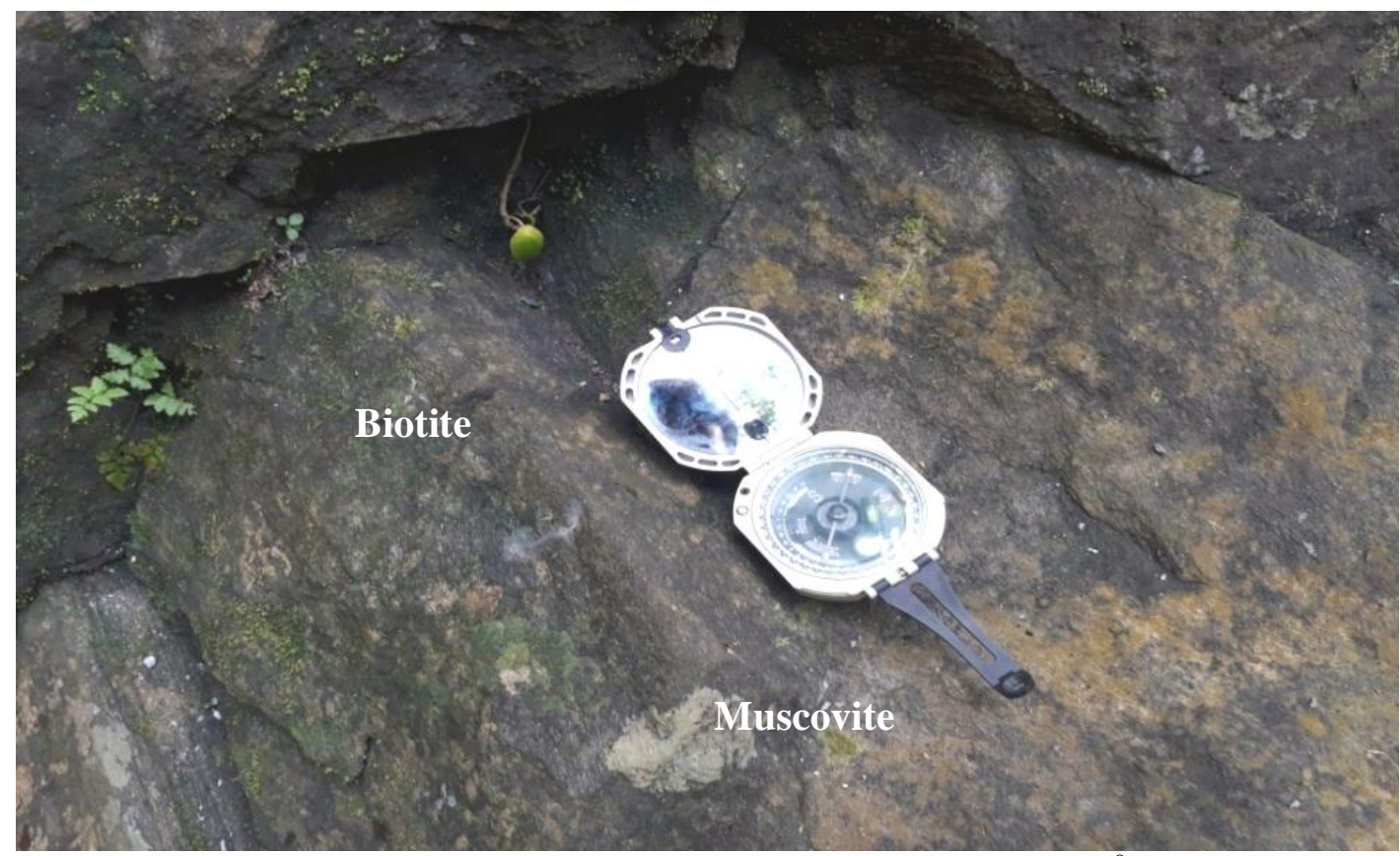

Figure 2. Mica schist rocks with photo direction N $250^{\circ} \mathrm{E}$ 
Each mineral description that formed rock could be seen in the table 2 below.

Table 2. The Description of Minerals of Rock Framer in Mica Schist

\begin{tabular}{cccc}
\hline No. & Mineral & Percentage & Mineral Description \\
\hline 1. & Muscovite & 70 & $\begin{array}{c}\text { Gray, white spout, glass luster, perfect cleavage, } \\
\text { concoidal fracture, 2.5 Mohs hardness scale }\end{array}$ \\
2. & Quartz & 15 & $\begin{array}{c}\text { White-colored, white spout, glass luster, no cleavage, } \\
\text { concoidal fracture, } 6.5-7 \text { Mohs hardness scale }\end{array}$ \\
3. & Biotite & 15 & $\begin{array}{c}\text { Black, black spout, glass luster, no cleavage, concoidal } \\
\text { fracture, hardness 2.5 Mohs hardness scale }\end{array}$ \\
\hline
\end{tabular}

Table 3 shows the result mica schist mineral sample.

Table 3. Rock Framer of Mica Schist Identification

\begin{tabular}{|c|c|c|}
\hline $\begin{array}{l}\text { Sample } \\
\text { Number }\end{array}$ & $\begin{array}{c}\text { Structure } \\
\text { type }\end{array}$ & Microscopic \\
\hline 1 & schistosic & $\begin{array}{l}\text { The slice was purplish blue-shaped, lepidoblastic in texture, mineral } \\
\text { composition formed of muscovite, quartz, biotite and opaque } \\
\text { minerals. }\end{array}$ \\
\hline 3 & schistosic & $\begin{array}{l}\text { The slice was purplish blue-shaped, lepidoblastic in texture, mineral } \\
\text { composition formed of muscovite, quartz and opaque minerals. }\end{array}$ \\
\hline 4 & schistosic & $\begin{array}{l}\text { The slice was purplish blue-shaped, lepidoblastic in texture, mineral } \\
\text { composition formed of muscovite, quartz and opaque minerals. }\end{array}$ \\
\hline 6 & schistosic & $\begin{array}{c}\text { This stone slice was brown, lepidoblastic texture, mineral } \\
\text { composition formed of muscovite, quartz, biotite and opaque } \\
\text { minerals. }\end{array}$ \\
\hline 7 & schistosic & $\begin{array}{l}\text { This slice was purplish blue-shaped, lepidoblastic in texture, mineral } \\
\text { composition formed of muscovite, quartz, oxide minerals and opaque } \\
\text { minerals. }\end{array}$ \\
\hline 8 & schistosic & $\begin{array}{l}\text { The slice was purplish blue-shaped, lepidoblastic in texture, mineral } \\
\text { composition formed of muscovite, quartz, biotite and opaque } \\
\text { minerals. }\end{array}$ \\
\hline 9 & schistosic & $\begin{array}{c}\text { The stone slice was purplish blue-shaped, lepidoblastic texture, } \\
\text { mineral composition formed of muscovite, quartz and opaque } \\
\text { minerals. }\end{array}$ \\
\hline 11 & schistosic & $\begin{array}{l}\text { The stone slice was purplish blue-shaped,lepidoblastic texture, } \\
\text { mineral composition formed of muscovite and quartz. }\end{array}$ \\
\hline 12 & schistosic & $\begin{array}{l}\text { The slice was purplish blue-shaped, lepidoblastic in texture, mineral } \\
\text { composition formed of muscovite, quartz, biotite and opaque } \\
\text { minerals. }\end{array}$ \\
\hline
\end{tabular}

Figures 3 and 4 illustrate the result mica schist mineral sample 


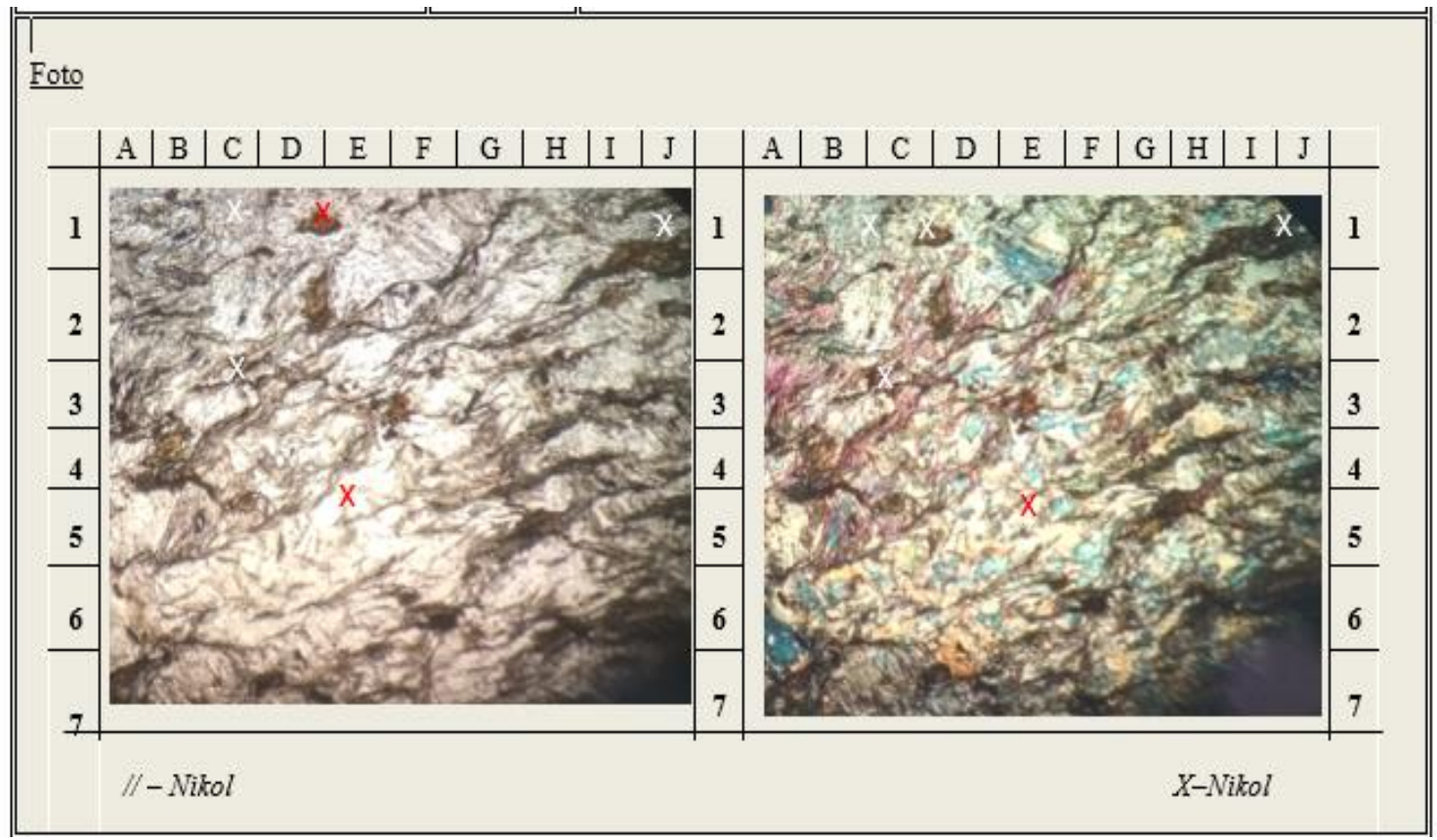

Figure 3. Mica schist sample number 1

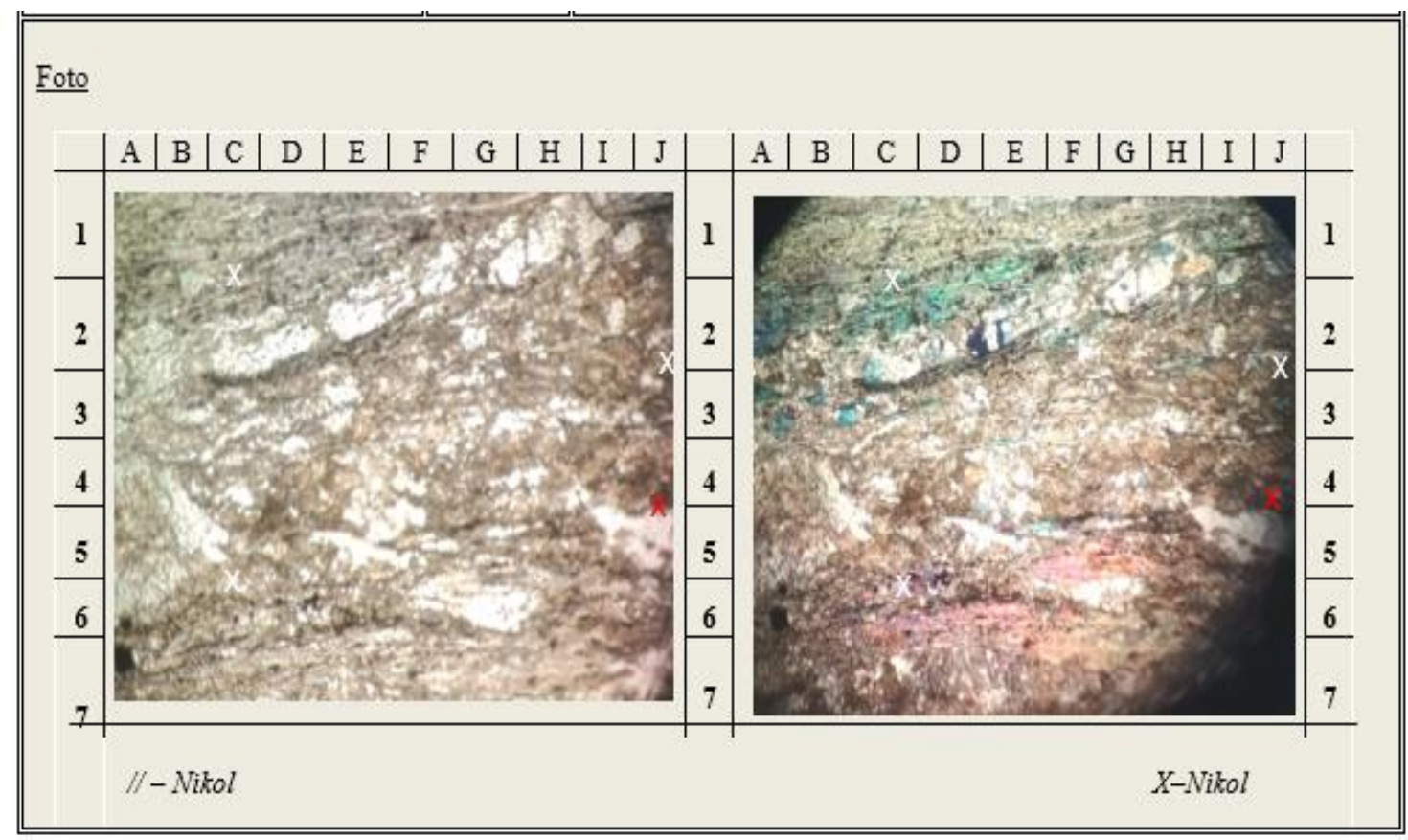

Figure 4. Mica schist sample number 12

The description of macroscopic and microscopic of the chlorite schist. Macroscopically, it had gray-colored appearance in fresh conditions and brown in weathered conditions. The rock texture was lepidoblastic with foliation rock structure. Mineral composition were chlorite and muscovite. Figure 5 shows the rock in the chlorite schist location. 


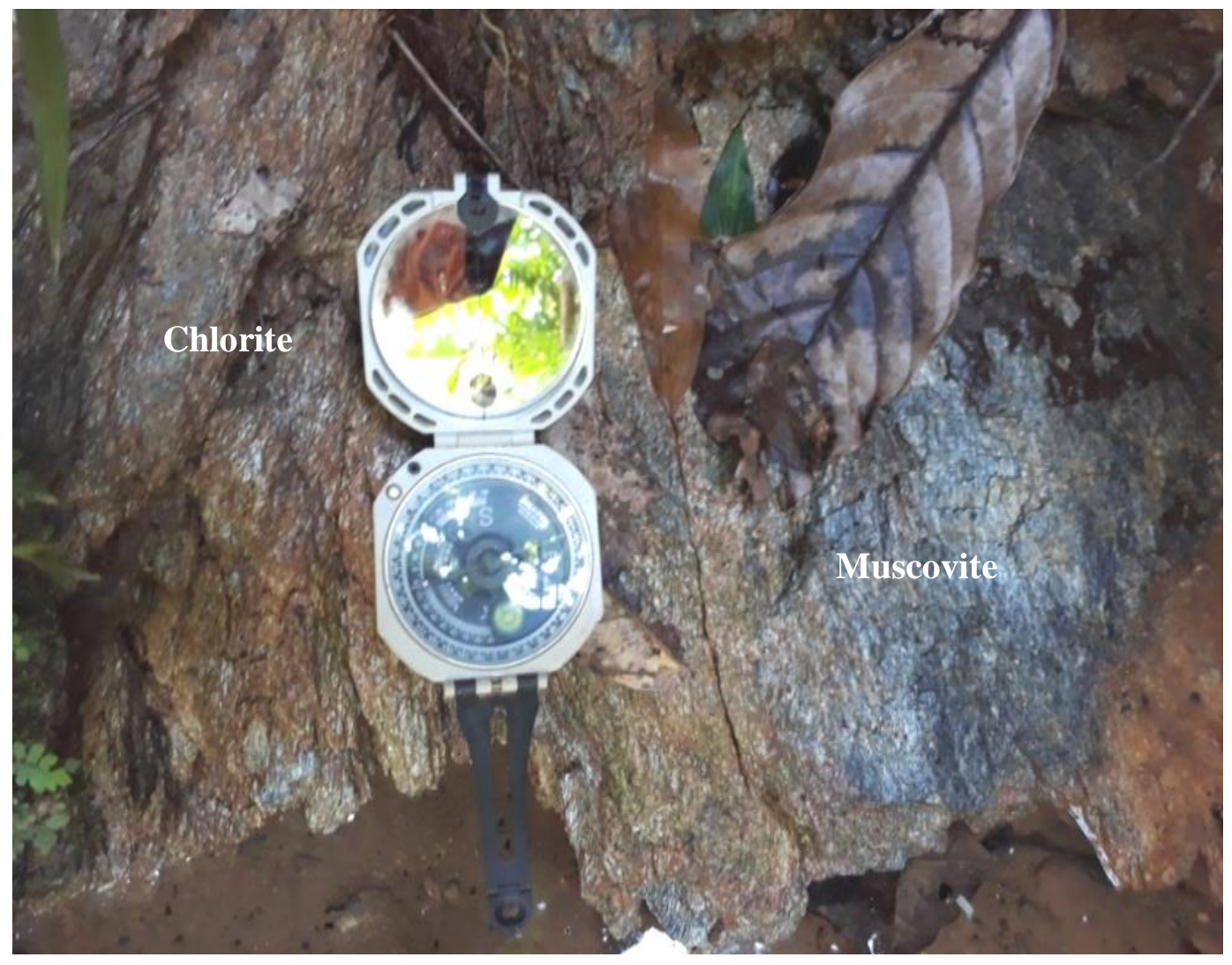

Figure 5. Chlorite schist rocks with photo direction $\mathrm{N} 162^{0} \mathrm{E}$

Each mineral description that formed rock could be seen in the table 4 below.

Table 4. The Description of Rock Framer Minerals of Chlorite Schist

\begin{tabular}{cccc}
\hline No & Mineral & Percentage & Mineral Description \\
\hline 1. & Chlorite & 70 & $\begin{array}{c}\text { Greenish, white spout, glass luster, no cleavage, } \\
\text { concoidal fracture, 2.5 Mohs hardness scale }\end{array}$ \\
2. & Muscovite & 15 & $\begin{array}{c}\text { Gray, white spout, glass luster, perfect cleavage, } \\
\text { concoidal fracture, 2.5 Mohs hardness scale }\end{array}$ \\
\hline
\end{tabular}

Table 5 shows the result chlorite schist mineral sample.

Table 5. Rock Framer of Chlorite Schist Identification

\begin{tabular}{ccc}
$\begin{array}{c}\text { Sample } \\
\text { Number }\end{array}$ & $\begin{array}{c}\text { Structure } \\
\text { type }\end{array}$ & Microscopic \\
\hline 2 & schistosic & $\begin{array}{r}\text { These rock slices were green, lepidoblastic texture, mineral } \\
\text { formed of chlorite and muscovite. }\end{array}$ \\
5 & schistosic & $\begin{array}{r}\text { These rock slices were green, lepidoblastic in texture, } \\
\text { mineral composition formed of chlorite and muscovite. }\end{array}$ \\
10 & schistosic & $\begin{array}{r}\text { This slice of rock was grayish green, lepidoblastic in texture, } \\
\text { mineral formed of chlorite, quartz and opaque minerals. }\end{array}$ \\
\hline
\end{tabular}


Figure 6 and 7 present the result of chlorite schist mineral sample.

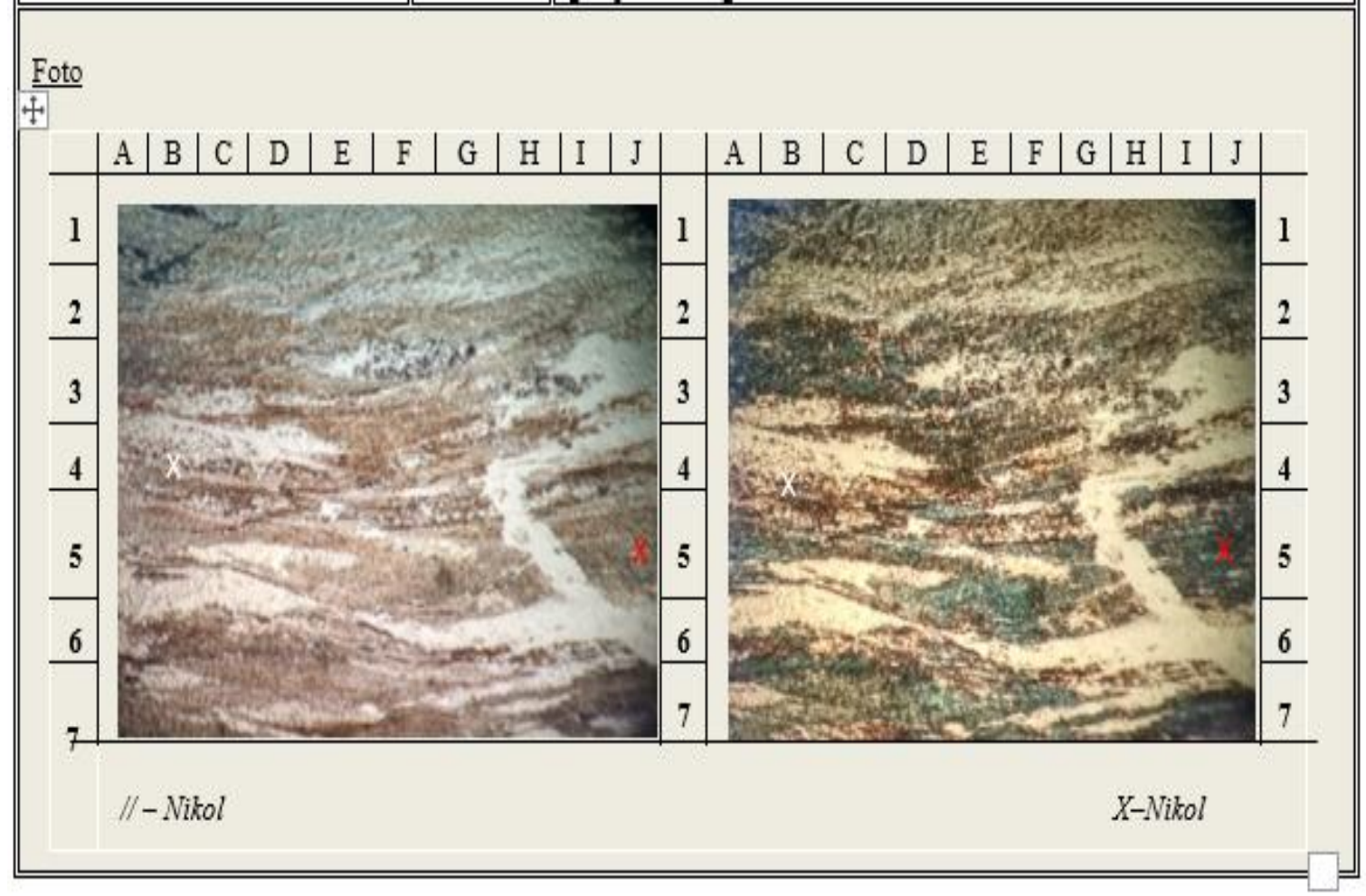

Figure 6. Chlorite schist sample number 2

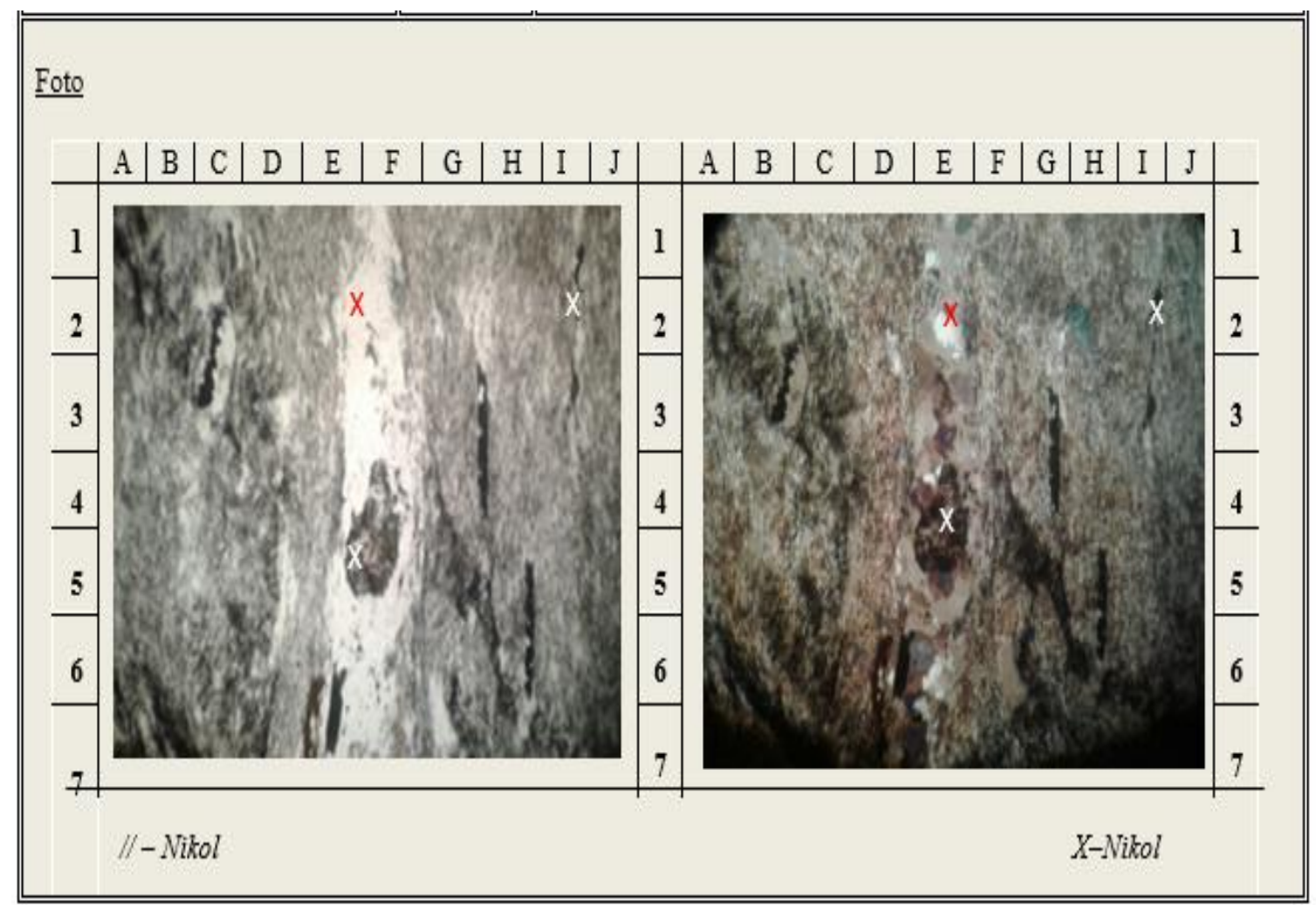

Figure 7. Chlorite schist sample number 10

The metamorphic descriptions in megascopic are based on color appearance, texture, structure and mineral composition. Color is a physical property of minerals that can be 
directly observed. Color does not entirely reflect the original color of the mineral, since the mineral color is not only derived from the mineral itself, but also occurs from other substances which pollute the mineral. According to (Nelson Eby et al., 2015) first identification and description relating to mineral is based on the color, for example the glass green in color.

Lepidoblastic texture is a metamorphic rock texture based on mineral form, this texture is dominated by the presence of flat rock-forming minerals. Foliation structure is the presense of a planar structure in a rock mass. According to (Bucher \& Rodney, 2011) the texture and structure of the rock characterize the identification of rock minerals, one of which is the foliation structure. According to (Cárdenes et al., 2013) the mica matric of muscovite has typical lepidoblastic texture.

This foliation could occur due to the juxtaposition of minerals into layers (gneissossity), grain orientation (schistossity), planar cleavage surface (cleavage). Foliation is can combine of its. According to (USDA, 2012) foliation shaped from gneissosity, schistosity, cleavage, and banned rock with code 7-10. According to (Song \& Suh, 2014) across foliation could be found upon rock samples that were taken in the mid-west region of South Korea.

Mica schist microscopically had purplish-blue, lepidoblastic texture, schistose structure. The mineral composition composed of muscovite, quartz, biotite, and opaque minerals. Figure 8 shows the rock figure found in the mica schist of the small slice.



Figure 8. Schist mica rock in the small slice (a) muscovite, (b) quarts, (c) biotite, (d) opaque mineral, (e) clay mass based 
Each mineral description that formed rock could be seen in the table 6 below.

Table 6. Optic Description of Mica Schist Mineral

\begin{tabular}{|c|c|c|}
\hline Mineral Composition & Percentage & Optic Mineral Information \\
\hline Muscovite (a) & 50 & $\begin{array}{l}\text { Purplish blue-colored interference, dichroic pleochroism, } \\
\text { subhedral shape, } 1 \text {-way cleavage, no fracture, high relief, } \\
\text { high intensity, mineral size } 0.01-0.10 \mathrm{~mm} \text {, darkenss angle } \\
42^{\circ} \text {, oblique darkness type. }\end{array}$ \\
\hline Quarts (b) & 15 & $\begin{array}{l}\text { Grayish white interference color, dichroic pleochroism, } \\
\text { subhedral-anhedral shaped, no cleavage, no fracture, low } \\
\text { relief, low intensity, mineral size } 0.02-0.5 \mathrm{~mm} \text {, darkness } \\
\text { angle } 47^{\circ} \text {, corrugated darkness type. }\end{array}$ \\
\hline Biotite (c) & 15 & $\begin{array}{l}\text { Brown interference color, dichroic pleochroism, subhedral- } \\
\text { anhedral shaped, no cleavage, no fracture, moderate relief, } \\
\text { moderate intensity, mineral size } 0.02-0.5 \mathrm{~mm} \text {, darkness } \\
\text { angle } 90^{\circ} \text {, parallel darkness type. }\end{array}$ \\
\hline Opaque Mineral (d) & 10 & $\begin{array}{l}\text { Colorless, anhedral (glass) shaped, low intensity, low } \\
\text { relief, size } 0.1-0.10 \mathrm{~mm} .\end{array}$ \\
\hline Clay Mass Base (e) & 10 & $\begin{array}{l}\text { Black, translucent, subhedral-anhedral shaped, the high } \\
\text { mineral intensity with high relief and mineral size } 0.02- \\
\qquad 0.08 \mathrm{~mm} \text {. }\end{array}$ \\
\hline
\end{tabular}

Chlorite schist microscopically was green-colored, lepidoblastic texture, schistocic structure. Mineral composition composed of chlorite and muscovite. Figure 9 shows the rock figure found in chlorite schist of the small slice.

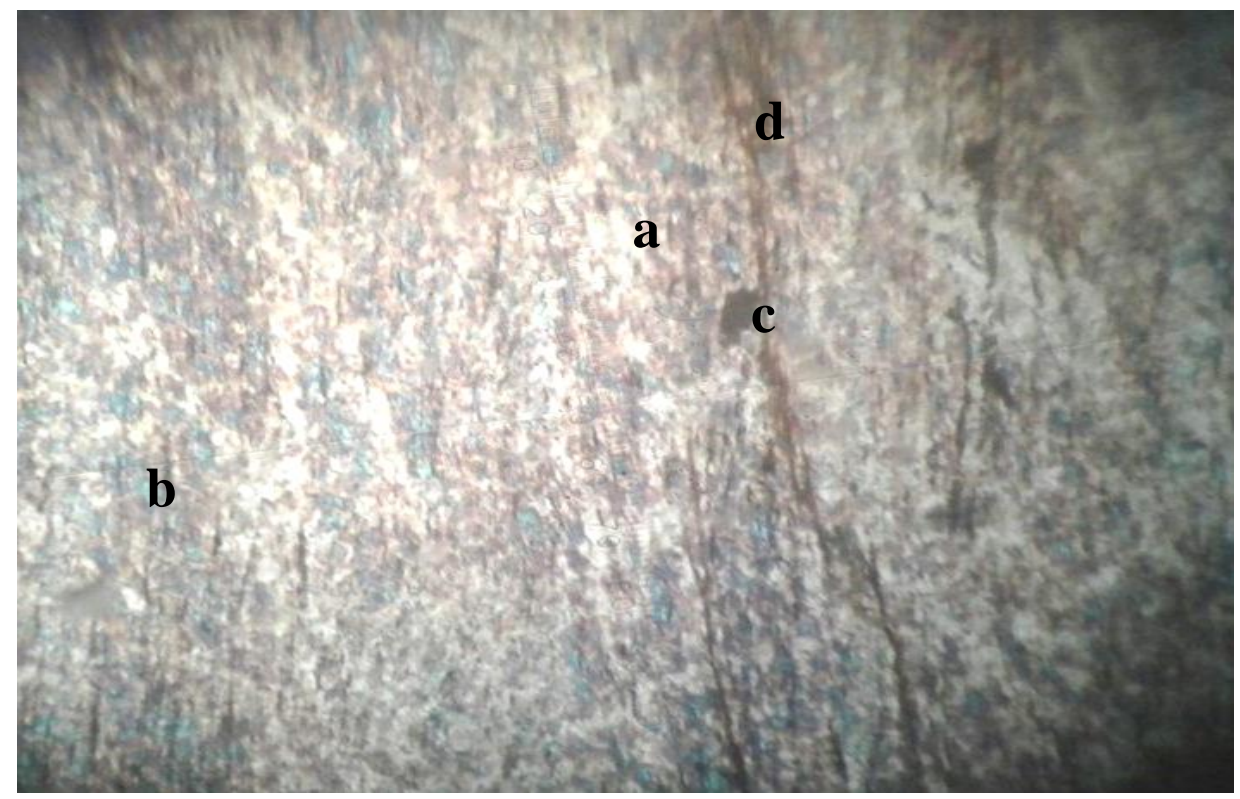

Figure 9. Schist chlorite rock in the small slice: (a) muscovite, (b) chlorite, (c) opaque mineral, (d) oxide mineral 
Each mineral description that formed rock could be seen in table 7 .

Table 7. Optic Description of Chlorite Schist Mineral

\begin{tabular}{|c|c|c|}
\hline $\begin{array}{c}\text { Mineral } \\
\text { Composition }\end{array}$ & Percentage & Optic Mineral Information \\
\hline Muscovite (a) & 20 & $\begin{array}{l}\text { Purplish blue-colored interference, dichroic } \\
\text { pleochroism, subhedral-shaped, 1-way cleavage, no } \\
\text { fracture, high relief, high intensity, mineral size } 0.01 \text { - } \\
0.8 \mathrm{~mm} \text {, darkenss angle } 38^{\circ} \text {, oblique darkness type. }\end{array}$ \\
\hline Chlorite (b) & 65 & $\begin{array}{l}\text { Green interference-colored, dichroic pleochroism, } \\
\text { anhedral-shaped, 1-way cleavage, no fracture, high } \\
\text { relief, high intensity, mineral size } 0.01-0.10 \mathrm{~mm}, \\
\text { darkness angle } 27^{\circ} \text {, oblique darkness type. }\end{array}$ \\
\hline Opaque Mineral (d) & 5 & $\begin{array}{l}\text { Black, translucent, subhedral-anhedral shaped, the } \\
\text { high mineral intensity with high relief and mineral } \\
\text { size } 0.01-0.2 \mathrm{~mm} \text {. }\end{array}$ \\
\hline Oxide Mineral (e) & 10 & $\begin{array}{l}\text { Brown, anhedral-shaped, the moderate mineral } \\
\text { intensity, moderate relief, and mineral size 0.01-0.8 } \\
\mathrm{mm} \text {. }\end{array}$ \\
\hline
\end{tabular}

The microscopic description of metamorphic rocks is based on color appearance, texture, structure, and mineral composition. Color is a representation of absorption appearance or wave length absorption upon light entering anisotropic minerals. Lepidoblastic texture is a metamorphic rock texture composed of mineral form, this texture is dominated by the presence of flat rock-forming minerals. Foliation structure is the appearance of a planar structure in a rock mass. Foliation structures and concepts follow concepts (Ahmed et al., 2017; Bucher \& Rodney, 2011; USDA, 2012).

Observation of mineral colors with megascopic handkerchief samples was significantly different compared to color observation microscopically. Muscovite had dichroic pleochroism, since there were changes in two different colors, the shape of the mineral was observed by perceiving or observing the boundary areas as well as boundary lines of the mineral. Muscovite had a sub hedral mineral form, in which the crystal was limited to only a part of the crystal itself. According to (Singh et al., 2012) petrological samples have various type depending to the purpose, the megascopic or proximate analysis is thicker than microscopic or petgorraphic and chemical purpose. According to (Xu et al., 2017) the minerals of oregon sunstones have dicroic, due to the color shifting from red to green.

Rocks found in the research area were mica schist and chlorite schist. Mica schist was composed of muscovite, biotite, and quartz minerals. Chlorite schist was composed of 
chlorite, muscovite and quartz minerals. The four minerals were flat-shaped, each rock had a schistose structure and lepidoblastic in texture, naming the structure and texture referring to the structure and texture type division according to (USDA, 2012). Schistose is a foliation structure produced by the alignment of relatively large flat minerals such as mica and chlorite. Lepidoblastic is a metamorphic rock texture that is dominated by flat minerals and shows a parallel orientation such as biotite and muscovite minerals.

The determination of the type of protolith rock was based on the petrographic analysis. Through thin slice petrography analysis, it was recognized that the metamorphic rock in the research area was dominated by quartz and muscovite minerals, a side from there was also a clay base mass, which indicated the protolith of the schist within research area was originated from sedimentary rock, namely claystone. According to (Bucher \& Rodney, 2011; Kohn, 2014; Lanari et al., 2019) slicing is a technique to anaylize rocks and minerals.

Based on schist constituent mineral in the research area, it was divided into 6 mineral groups. The rock constituent minerals were chlorite and muscovite; chlorite and quartz; muscovite and quartz; muscovite, quartz, biotite, and chlorite; muscovite, quartz, and biotite; biotite and quartz. According to (Lewerentz, 2017) the mineral assemblage of chlorite and muscovite, chlorite and quartz, as well as muscovite and quartz are embodied into chlorite zone which is characterized by the presence of quartz, chlorite, muscovite and albite minerals. Furthermore (Lewerentz, 2017) describes the set of mineral muscovite, quartz, biotite and chlorite; muscovite, quartz and biotite; and biotite and quartz are embodied into the biotite zone which is characterized by the presence of quartz, muscovite, biotite, chlorite, and albite minerals.

Other reinforcement concepts by (Kohn, 2014) related to names given to various facies. The name is based on a set of mineral groups that will develop in mass mafic compositions under various pressure, temperature and mineral conditions that define each facies. Especially related to temperature through temperature-time analysis.

Based on zoning by (Lewerentz, 2017), schist of the study area was embodied into the chlorite zone and biotite zone, both zones were included in the greenschist facies with index minerals, namely chlorite. Chlorite was located at the bottom of the schist, then with high temperature of the greenschist the low-schist green high was characterized by the presence of biotite with $425^{\circ}-450^{\circ} \mathrm{C}$ temperature, in line with the metamorphism facies chart by (Kohn, 2014). According to (Noor et al., 2016) the greenschist facies are characterized by chlorite, biotite, muscovite, clay, and codierite. 
According to the metamorphic rocks observation of the research area, it had a foliation structure. Foliation structure was marked through the alignment of metamorphic minerals and schistosic structures, a structure in which flat minerals (biotite, muscovite) were more dominant than granular minerals. This structure was primarily a result of a regional metamorphosis process, very typical were the clear pieces of flat minerals such as mica, chlorite and fibers mineral. According to (Bucher \& Rodney, 2011) regional metamorphism occurs in a significant wide area while local metamorphism occurs in quite a narrow area ranging from a few meters to kilometers. According to (Candan et al., 2016) the gabbroic dikes in Tauride Block, Western Turkey is one of several small locations samples that is wellpreserved as locally metamorphic rock converted into eclogitic metagabbros and amphibolites.

There have been limited studies concerning on how to determine the mineral (facies and metamorphism type such depositional by (Nugraha \& Hall, 2018), nutrients by (Moniruzzaman et al., 2014), and Digital Elevation Model (DEM) by (Kurnianto \& Nurdin, 2020). The research finding was related to the determination of facies and metamorphism types of metamorphic rock. According to (Moniruzzaman et al., 2014) the determination of minerals occupies important information about mineral from various regions for human life benefits. The finding research indicated the minerals determination within mekongga complex section that mica schist and chlorite schist were included in the greenschist facies and regional metamorphis process. Prior this, the mineral was described macroscophic and microscophic. This revealed the research novelty, that the facies and metamorphis type part of mekongga complex in Lambolemo Village displayed differences towards the findings of the metamorphic rocks that were not contained neither in the geological map nor the other rock research, specially in the mekongga complex section.

\section{Consclusion}

The metamorphic rocks in Lambolemo Village as part of mekongga complex reveals that mica schist and chlorite schist obtain lepidoblastic textures. The mica schist composed of muscovite, quartz, biotite, and opaque minerals. The chlorite schist composition formed of chlorite and muscovite. The schist mineral was embodied into the chlorite zone and biotite zone, both zones were embodied to wards the greenschist facies. Both mica schist and chlorite schist metamorphism types were regional metamorphism. 


\section{Conflict of Interest}

The authors declare that there is no conflict of interest with any financial, personal, or other relationships with other people or organizations related to the material discussed in the article.

\section{Acknowledgments}

Thanks to Universitas Sembilanbelas November Kolaka and the collaboration team in the Universiti Tun Hussein Onn Malaysia, Universitas Jember, and Universitas Halu Oleo that developed the engineering geography topic.

\section{References}

Ahmed, K. J., Zaki, M. M., Rizvi, H. A., Zoheb, M. M., \& Ansari, A. S. (2017). A review on rock cycle. International Journal of Emerging Technologies and Innovative Research, 4(12), 100-102. http://www.jetir.org/papers/JETIR1712021.pdf.

Amaluddin, L. O., Rahmat, R., Surdin, S., Ramadhan, M. I., Hidayat, D. N., Sejati, A. E., Purwana, I. G., \& Fayanto, S. (2019). The effectiveness of outdoor learning in improving spatial intelligence. Journal for the Education of Gifted Young Scientists, 7(3), 667-680. https://doi.org/10.17478/jegys.613987.

Anggara, F., Pamungkas, D., \& Prakoso, W. G. (2018). Canwe identify macroscopic texture of coal under microscopic analysis using standard petrographic method?.Journal of Applied Geology, 3(1), 32. https://doi.org/10.22146/jag.40005.

Bucher, K., \& Rodney, G. (2011). Petrogenesis of Metamorphic Rocks. London: Sparinger. https://doi.org/10.1007/978-3-540-74169-5.

Ca, A., Oj, A., \& Lo, A. (2019). Empirical relationship between gravimetric and mechanical properties of basement rocks in Ado-Ekiti, Southwestern Nigeria. J Geol Geophys, 9(1), 1-14. https://doi.org/10.35248/2381-8719.19.9.470.

Candan, O., Koralay, O. E., Topuz, G., Oberhänsli, R., Fritz, H., Collins, A. S., \& Chen, F. (2016). Late Neoproterozoic gabbro emplacement followed by early cambrian eclogitefacies metamorphism in the Menderes Massif (W. Turkey): Implications on the final assembly of Gondwana. Gondwana Research, 34(1), 158-173. https://doi.org/10.1016/j.gr.2015.02.015.

Cárdenes, V., Rubio-Ordoñez, A., Monterroso, C., \& Calleja, L. (2013). Geology and geochemistry of iberian roofing slates. Chemie Der Erde, 73(3), 373-382. https://doi.org/10.1016/j.chemer.2012.11.004.

Chen, Q., Zhao, Z., Jiang, Q., Tan, S., \& Tian, Y. (2018). Identification of metamorphic rocks in Wuliangshan Mountains (Southwest China) using aster data. Arabian Journal of Geosciences, 11(12), 1-18. https://doi.org/10.1007/s12517-018-3635-y. 
Geng, Y., Shen, Q., \& Song, H. (2018). Metamorphic petrology and geology in China: A review. China Geology, 1(1), 137-157. https://doi.org/10.31035/cg2018012.

Hamimu, L., Ngkoimani, L. O., Jahidin, J., Asfar, S., \& Usmardin, U. (2019). Analysis of the sub-surface distribution of graphite minerals using the geoelectrical resistivity method in the Sabilambo Village, Kolaka Regency,Southeast Sulawesi Province. Journal of Geoscience, Engineering, Environment, and Technology, 4(3), 149-157. https://doi.org/10.25299/jgeet.2019.4.3.2406.

Hasria, H., Idrus, A., \& Warmada, I. W. (2017). The metamorphic rocks-hosted gold mineralization at rumbia mountains prospect area in the southeastern arm of Sulawesi Island, Indonesia. Journal of Geoscience, Engineering, Environment, and Technology, 2(3), 217-223. https://doi.org/10.24273/jgeet.2017.2.3.434.

Idrus, A., Prihatmoko, S., Gendoet Hartono, H., Idrus, F., \& Setiawan, I. (2014). Some key features and possible origin of the metamorphic rock-hosted gold mineralization in Buru Island, Indonesia. Indonesian Journal on Geoscience, 1(1), 9-19. https://doi.org/10.17014/ijog.v1i1.172.

Kohn, M. J. (2014). Himalayan Metamorphism and Its Tectonic Implications. Annual Review of Earth and Planetary Sciences, 42(1), 381-419. https://doi.org/10.1146/annurev-earth060313-055005.

Kurnianto, F A, \& Nurdin, E. A. (2020). Analysis of stratigraphy and lithology in forming gold minerals in East Java with digital elevation model and medium format photo. IOP Conf. Ser.: Earth Environ. Sci, 485, 12145. https://doi.org/10.1088/17551315/485/1/012145.

Kurnianto, Fahmi Arif, Apriyanto, B., Nurdin, E. A., Ikhsan, F. A., \& Fauzi, R. Bin. (2018). Geographic information system (gis) application to analyze landslide prone disaster zone in Jember Regency East Java. Geosfera Indonesia, 2(1), 45. https://doi.org/10.19184/geosi.v2i1.7524.

Lanari, P., Ferrero, S., Goncalves, P., \& Grosch, E. G. (2019). Metamorphic geology: progress and perspectives. In Geological Society Special Publication478(1), 1-12. https://doi.org/10.1144/SP478-2018-186.

Lewerentz, A. (2017). Fluid-induced alteration of metasedimentary rocks in the scottish highlands. Dissertation, Geology, Stockholm University. Retrieved from https://www.diva-portal.org/smash/get/diva2:1135383/FULLTEXT01.pdf.

Maulana, A., Jaya, A., \& Sitha, K. (2018). Field characteristic of metamorphic-hosted gold deposit in Sulawesi, Indonesia: An insight into awak mas prospect, South Sulawesi. International Journal of Engineering and Science Application, 4(2), 105-112. http://pasca.unhas.ac.id/ojs/index.php/ijesca/article/view/1385.

Moniruzzaman, M., Alamgir, M., Chowdhury, Z., Rahman, M. A., Sulaiman, S. A., \& Gan, S. H. (2014). Determination of mineral, trace element, and pesticide levels in honey samples originating from different regions of Malaysia compared to manuka honey. Biomed 
https://doi.org/10.1155/2014/359890.

Nelson Eby, G., Charnley, N., Pirrie, D., Hermes, R., Smoliga, J., \& Rollinson, G. (2015). Trinitite redux: Mineralogy and petrology. American Mineralogist, 100(2-3), 427-441. https://doi.org/10.2138/am-2015-4921.

Noor, M. K., Tonggiroh, A., \& Maulana, A. (2016). Type of gold hydrothermal deposits on metamorphic rock District Buru, Province Maluku. International Journal of Engineering and Science Applications, 3(1), 39-45. http://pasca.unhas.ac.id/ojs/index.php/ijesca/article/view/276.

Nugraha, A. M. S., \& Hall, R. (2018). Late cenozoic palaeogeography of Sulawesi, Indonesia. Palaeogeography, Palaeoclimatology, Palaeoecology, 490, 191-209. https://doi.org/10.1016/j.palaeo.2017.10.033.

Nursalam, L. O., Arisona, A., Harudu, L., Harianto, E., \& Kasmiati, S. (2019). Mapping of Subsurface Geological Structure and Land Cover Using Microgravity Techniques for Geography and Geophysic Surveys : A Case Study of Maluri Park , Malaysia. Geosfera Indonesia, 4(3), 280-290.

Setiawan, N. I., Osanai, Y., Nakano, N., Adachi, T., \& Asy’ari, A. (2015). Metamorphic evolution of garnet-bearing epidote-barroisite schist from the meratus complex in South Kalimantan, Indonesia. Indonesian Journal on Geoscience, 2(3), 139-156. https://doi.org/10.17014/ijog.2.3.139-156.

Singh, P. K., Singh, M. P., Singh, A. K., Naik, A. S., Singh, V. K., Singh, V. K., \& Rajak, P. K. (2012). Petrological and geochemical investigations of rajpardi lignite deposit, Gujarat, India. Energy Exploration \& Exploitation, 30(1), 131-151. https://doi.org/10.1260/0144-5987.30.1.131.

Soesilo, J., Schenk, V., Suparka, E., \& Abdullah, C. I. (2015). The mesozoic tectonic setting of se sundaland based on metamorphic evolution. Proceedings Indonesian Petrolium Association. http://archives.datapages.com/data/ipa_pdf/2015/ipa15-g-205.htm.

Song, I., \& Suh, M. (2014). Effects of foliation and microcracks on ultrasonic anisotropy in retrograde ultramafic and metamorphic rocks at shallow depths. Journal of Applied Geophysics, 109, 27-35. https://doi.org/10.1016/j.jappgeo.2014.07.011.

Surono. (2013). Geologi Regional Sulawesi Tenggara. Badan Geologi Kementerian Energi dan Sumberdaya Mineral. Retrieved from https://www.academia.edu/35832171/Geologi_Regional_Sulawesi_Tenggara?auto=dow nload.

Tóth, T. M., \& Schubert, F. (2018). Evolution of the arc-derived orthogneiss recorded in exotic xenoliths of the körös complex (tisza megaunit, SE Hungary. Journal of Geosciences (Czech Republic), 63(1), 21-46. https://doi.org/10.3190/jgeosci.253.

USDA. (2012). Geology National Engineering Handbook Chapter: Engineering Classification of Rock Materials.Washington DC: United States Department of 
Agriculture, Natural Resources Conservation Service.

Xu, H., Hill, T. R., Konishi, H., \& Farfan, G. (2017). Protoenstatite: A new mineral in Oregon sunstones with "watermelon" colors. American Mineralogist, 102(10), 2146-2149. https://doi.org/10.2138/am-2017-6186 